\title{
Microstructural evolution of mullite during the sintering of kaolin powder compacts
}

\author{
C.Y. Chen, G.S. Lan, W.H. Tuan* \\ Institute of Materials Science and Engineering, National Taiwan University, Taipei, 106 Taiwan, ROC
}

Received 20 September 1999; received in revised form 12 November 1999; accepted 19 November 1999

\begin{abstract}
Kaolin particles are usually flaky in shape. In the present study, kaolin powder compacts were prepared by applying the diepressing technique. The kaolin flakes tend to lie down on the plane which is perpendicular to the die-pressing direction. The powder compact thus shows anisotropic shrinkage after firing. A series of phase transformations take place as the kaolin is fired at elevated temperature. Mullite is first formed at a temperature as low as $1100^{\circ} \mathrm{C}$. If the firing temperature is higher than $1400^{\circ} \mathrm{C}$, needleshaped mullite grains are formed. The size and the aspect ratio of the mullite grains increase with the increase of firing temperature. Furthermore, the long axes of the mullite needles tend to be perpendicular to the die-pressing direction. (C) 2000 Elsevier Science Ltd and Techna S.r.l. All rights reserved.
\end{abstract}

Keywords: A. Sintering; B. Microstructure-final; D. Mullite

\section{Introduction}

Kaolin, a relatively pure clay, has been widely used in ceramic industries for centuries [1]. Kaolin is, therefore, one of the most important raw materials for ceramic industries. Though kaolin has been used for many years, to explore the complexities involved in its phase transformation and microstructural evolution at elevated temperature is still a challenging task [2]. The main product phase after firing kaolin at high temperature is mullite. Mullite is, thus, an important constituent in refractories, whitewares and structural clay products for kaolin is frequently used as the raw material.

Mullite itself is very stable at high temperature. Furthermore, its thermal expansion coefficient and dielectric loss are low; mullite is, therefore, widely used as thermal and electrical insulation components. Many approaches have been used to prepare mullite. However, the interdiffusion rates of $\mathrm{Si}^{4+}$ and $\mathrm{Al}^{+3}$ within the mullite lattice are relatively slow [3], the kinetics of mullite formation by reaction thus depend strongly on the precursor mixing. For example, the mullitization

* Corresponding author. Tel.: + 886-2-2365-9800; fax: 886-2-23634562 .

E-mail address: tuan@ccms.ntu.edu.tw (W.H. Tuan). temperature for the solid state reaction between $\mathrm{Al}_{2} \mathrm{O}_{3}$ and $\mathrm{SiO}_{2}$ particles can be higher than $1650^{\circ} \mathrm{C}$ [3]. By coating amorphous $\mathrm{SiO}_{2}$ onto the surface of $\gamma-\mathrm{Al}_{2} \mathrm{O}_{3}$ particles, the mullite can form at a temperature lower than $1300^{\circ} \mathrm{C}$ [4]. As $\mathrm{Al}, \mathrm{Si}$ and $\mathrm{O}$ are mixed at atomic level such as that prepared by a sol-gel technique, mullite is formed at a temperature around $1150^{\circ} \mathrm{C}$ [5]. Among the available approaches, to prepare mullite by using kaolin as starting material is an important one for its economic potential. Later, we are going to demonstrate that apart from the economic reason, the approach of using kaolin as starting material offers many benefits such as low processing temperature and unique microstructure.

\section{Experimental procedures}

A Malaysian kaolin powder was used in the present study. The constituents in the as-received powder as reported by the manufacturer were $\mathrm{SiO}_{2}(48.5 \mathrm{wt} \%)$, $\mathrm{Al}_{2} \mathrm{O}_{3}(35.5 \mathrm{wt} \%), \mathrm{K}_{2} \mathrm{O}(1.5 \mathrm{wt} \%), \mathrm{Fe}_{2} \mathrm{O}_{3}(1.0 \mathrm{wt} \%)$, $\mathrm{TiO}_{2}(0.4 \mathrm{wt} \%), \mathrm{MgO}(0.35 \mathrm{wt} \%), \mathrm{Na}_{2} \mathrm{O}(0.07 \mathrm{wt} \%)$, $\mathrm{CaO}(0.05 \mathrm{wt} \%)$ and an ignition loss of $12.6 \mathrm{wt} \%$. The powder compacts were prepared by a die-pressing technique. The firing was carried out at a temperature 
varied from 400 to $1600^{\circ} \mathrm{C}$ for $1 \mathrm{~h}$. The sintering kinetics of the powder compacts were also measured with a differential dilatometer (Theta Co., USA). The phase identification was performed by X-ray diffractometry (Philips PW1710, Philips Co., Netherlands) with $\mathrm{Cu} K_{\alpha}$ radiation. The final density was determined by Archimedes' method. The flexural strength of the rectangular specimens was determined by the three-point bending technique at ambient, room-temperature condition. The lower span for the flexural testing fixture was $30 \mathrm{~mm}$. The loading rate was $0.5 \mathrm{~mm} / \mathrm{min}$. The fracture toughness was determined by the 3-point single-edge-notchedbeam (SENB) technique. The notch was generated by cutting with a diamond saw. The width of the notch was around $0.45 \mathrm{~mm}$. The microstructure was observed by scanning electron microscopy (SEM). The morphology of mullite grains in the sintered specimens was also observed with SEM. To reveal the morphology of mullite grains, an etching solution, concentrated hydrofloride acid, was used to remove the glassy phase around the mullite grains in the sintered specimens.

\section{Results and discussion}

Fig. 1 shows the morphology of the kaolin particles. The kaolin particles are flaky in shape, Fig. 1(a). Some large kaolin flakes are stacked together to form agglomerates, Fig. 1(b). The XRD pattern of the kaolin powder is shown in Fig. 2(a). Apart from the kaolinite phase, a small amount of quartz is detected by the XRD analysis. The chemical composition of kaolinite is $\mathrm{Al}_{2} \mathrm{O}_{3}$ $2 \mathrm{SiO}_{2} 2 \mathrm{H}_{2} \mathrm{O}$. The amount of $\mathrm{SiO}_{2}$ for the above formula is $46.5 \mathrm{wt} \%$. However, there is $48.5 \mathrm{wt} \% \mathrm{SiO}_{2}$ presented in the as-received powder. The excess $\mathrm{SiO}_{2}$ found in the as-received powder is in the form of quartz. Furthermore, there is also a small amount of muscovite(mica) detected in the XRD pattern. The nominal composition of the mica is $(\mathrm{K}, \mathrm{Na})(\mathrm{Al}, \mathrm{Mg}, \mathrm{Fe})_{2}\left(\mathrm{Si}_{3.1}, \mathrm{Al}_{0.9}\right) \mathrm{O}_{10}$ $(\mathrm{OH})_{2}$. The XRD patterns of the planes perpendicular and parallel to the die-pressing direction are shown in Fig. 2(b) and (c), respectively. The intensity of the $\{001\}$ planes on the plane perpendicular to the diepressing direction is higher than that of the powder and of the plane parallel to the die-pressing direction. It indicates that most kaolin flakes tend to lie down on the plane which is perpendicular to the die-pressing direction.

The XRD patterns of the powder compacts heat treated at various temperatures are shown in Fig. 3. From the patterns and the previous studies [2,6-9], the kaolin powder compacts underwent a series of phase transformations as the temperature was raised from room temperature to $1600^{\circ} \mathrm{C}$. These phase transformations are

when $T=400-500^{\circ} \mathrm{C}$,
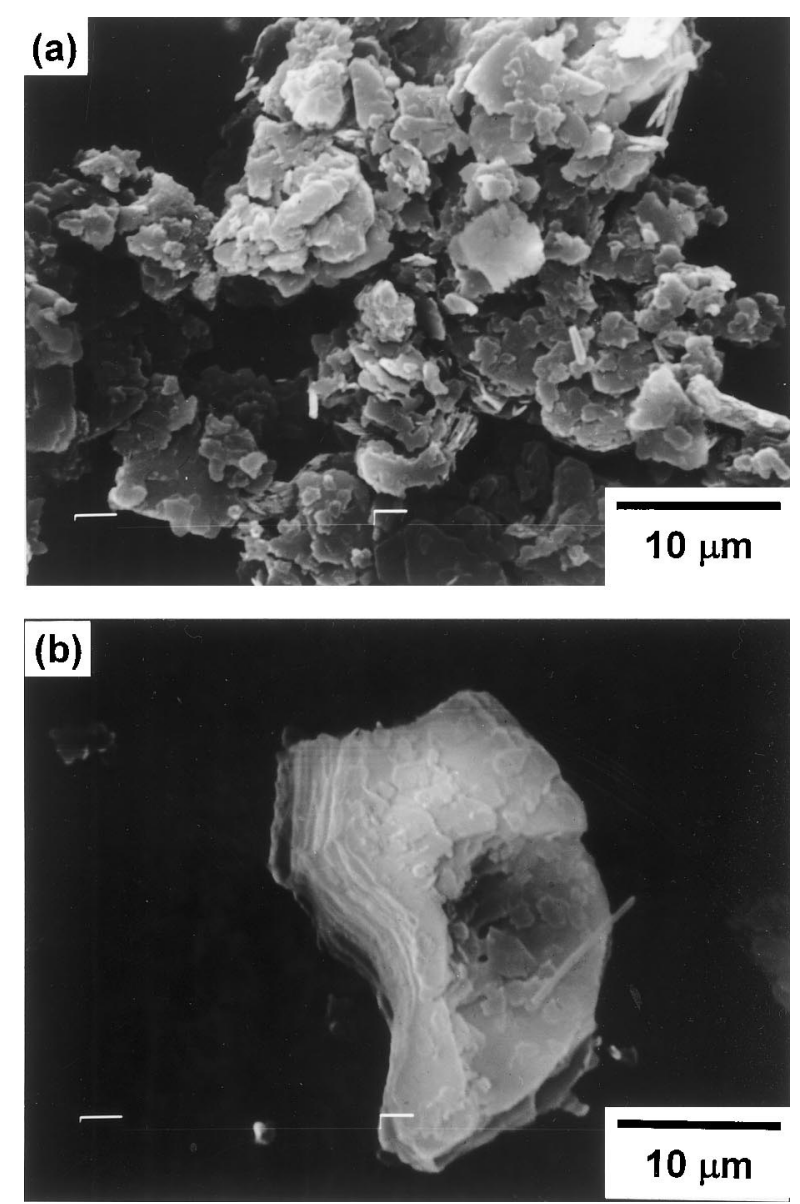

Fig. 1. The morphology of the kaolin particles.

$$
\begin{aligned}
& 2 \mathrm{SiO}_{2} \cdot \mathrm{Al}_{2} \mathrm{O}_{3} \cdot 2 \mathrm{H}_{2} \mathrm{O} \text { (kaolinite) } \\
& \quad=2 \mathrm{SiO}_{2} \cdot \mathrm{Al}_{2} \mathrm{O}_{3} \text { (metakaolinite) }+2 \mathrm{H}_{2} \mathrm{O}
\end{aligned}
$$

when $T \sim 980^{\circ} \mathrm{C}$,

$$
\begin{aligned}
2 \mathrm{SiO}_{2} \cdot \mathrm{Al}_{2} \mathrm{O}_{3} \text { (metakaolinite) } & =\mathrm{SiAl}_{2} \mathrm{O}_{4} \text { (spinel) } \\
& +\mathrm{SiO}_{2} \text { (amorphous) }
\end{aligned}
$$

or

$2 \mathrm{SiO}_{2} \cdot \mathrm{Al}_{2} \mathrm{O}_{3}($ metakaolinite $)=\mathrm{Al}_{2} \mathrm{O}_{3}(\gamma$-alumina $)$

$$
+2 \mathrm{SiO}_{2} \text { (amorphous) }
$$

when $T>1100^{\circ} \mathrm{C}$,

$\mathrm{SiAl}_{2} \mathrm{O}_{4}$ (spinel) $+\mathrm{SiO}_{2}$ (amorphous)

$=1 / 3\left(3 \mathrm{Al}_{2} \mathrm{O}_{3} \cdot 2 \mathrm{SiO}_{2}\right)($ mullite $)+4 / 3 \mathrm{SiO}_{2}$ (amorphous) 


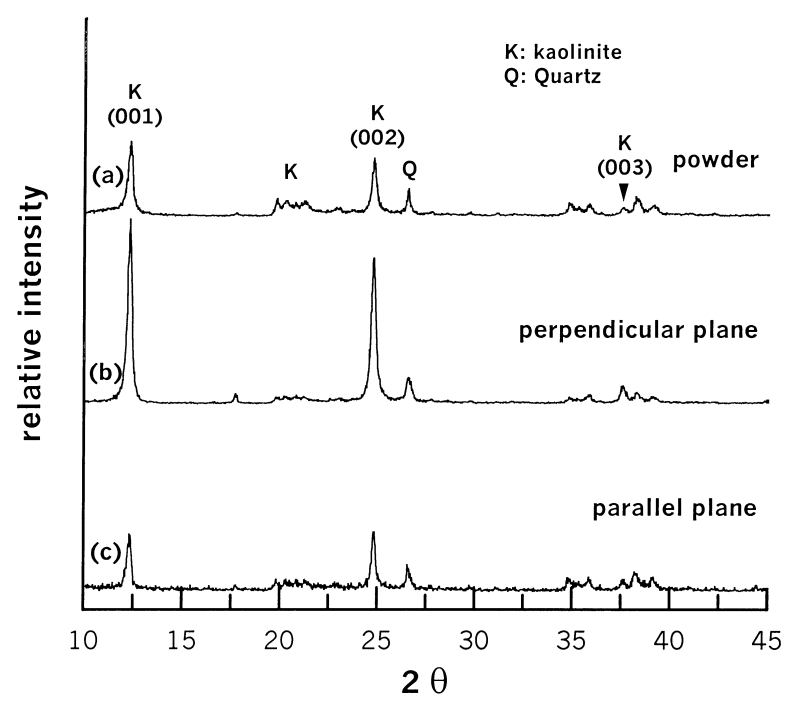

Fig. 2. The XRD patterns of (a) the kaolin powder and (b), (c) the powder compact. In (b) and (c) the plane taken is perpendicular and parallel to the die-pressing direction, respectively.

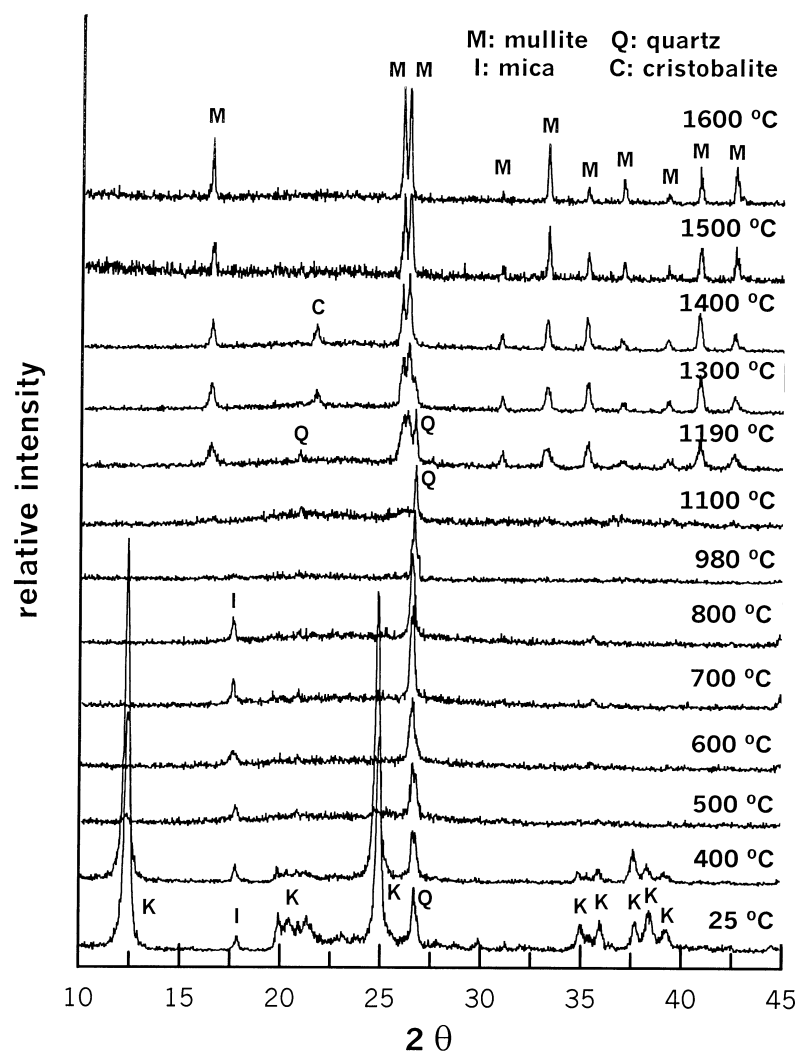

Fig. 3. The XRD patterns of the kaolin powder compacts after firing at various temperatures. The compact was kept at the indicated temperatures for $1 \mathrm{~h}$.

or

$$
\begin{aligned}
& \mathrm{Al}_{2} \mathrm{O}_{3}(\gamma \text {-alumina })+2 \mathrm{SiO}_{2} \text { (amorphous) } \\
& =1 / 3\left(3 \mathrm{Al}_{2} \mathrm{O}_{3} \cdot 2 \mathrm{SiO}_{2}\right)(\text { mullite })+4 / 3 \mathrm{SiO}_{2} \text { (amorphous) }
\end{aligned}
$$

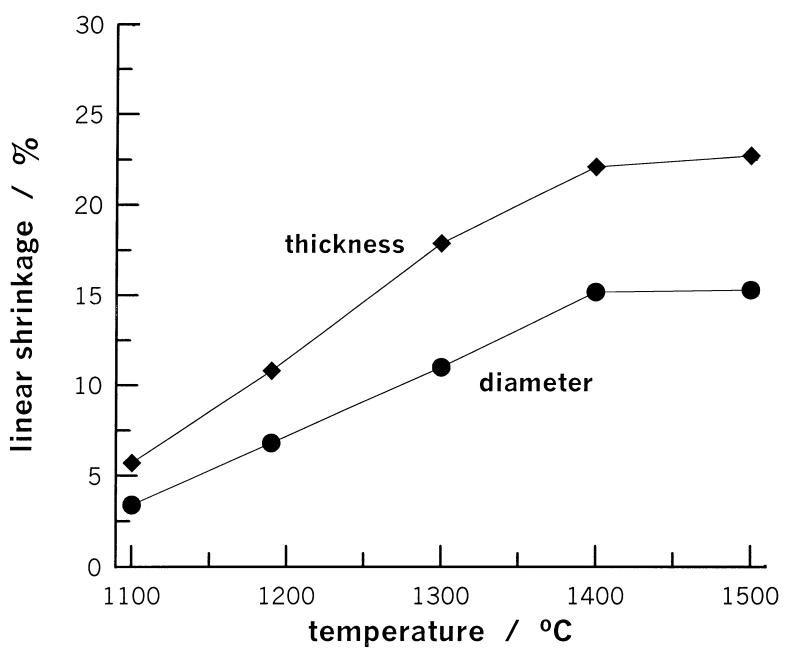

Fig. 4. The linear shrinkage of the powder compacts as a function of sintering temperature.

when $T>1200^{\circ} \mathrm{C}$,

$$
\begin{aligned}
& 3 \mathrm{Al}_{2} \mathrm{O}_{3} \cdot 2 \mathrm{SiO}_{2} \text { (mullite) }+4 \mathrm{SiO}_{2} \text { (amorphous) } \\
& \quad=3 \mathrm{Al}_{2} \mathrm{O}_{3} \cdot 2 \mathrm{SiO}_{2} \text { (mullite) }+4 \mathrm{SiO}_{2} \text { (cristobalite) }
\end{aligned}
$$

when $T>1500^{\circ} \mathrm{C}$,

$$
\begin{aligned}
& 3 \mathrm{Al}_{2} \mathrm{O}_{3} \cdot 2 \mathrm{SiO}_{2} \text { (mullite) }+4 \mathrm{SiO}_{2} \text { (cristobalite) } \\
& =3 \mathrm{Al}_{2} \mathrm{O}_{3} \cdot 2 \mathrm{SiO}_{2} \text { (mullite) }+4 \mathrm{SiO}_{2} \text { (amorphous) }
\end{aligned}
$$

The phase transformations are expressed in the form of chemical reactions for the ease of explanation. However, the above equations are not exactly balanced for many ceramic products and are more or less non-stoichiometric. Furthermore, the impurities in the starting powder can induce a liquid phase during firing. The presence of the liquid phase can shift slightly the formation temperature of each phase and its amount.

The kaolinite transforms to metakaolinite by removing the hydroxyl groups above the temperature of $400^{\circ} \mathrm{C}$. The metakaolinite then transforms to a spinel structure or a Si-containing $\gamma-\mathrm{Al}_{2} \mathrm{O}_{3}$ and amorphous silica at a temperature around $980^{\circ} \mathrm{C}[6,10,11]$. At that temperature, whether a spinel or a silicon-containing $\gamma$ $\mathrm{Al}_{2} \mathrm{O}_{3}$ is formed is still under debate. Mullite phase first appears at a temperature around $1100^{\circ} \mathrm{C}$, its amount increases with the increase of temperature. The amorphous $\mathrm{SiO}_{2}$ changes to cristobalite above $1200^{\circ} \mathrm{C}$, then changes to amorphous glass again above $1500^{\circ} \mathrm{C}$.

Fig. 4 shows the linear shrinkage of the compacts as a function of sintering temperature. The thickness shrinkage is larger than the diameter shrinkage; the powder compact shows anisotropic shrinkage after sintering. It mainly results from the preferred orientation 


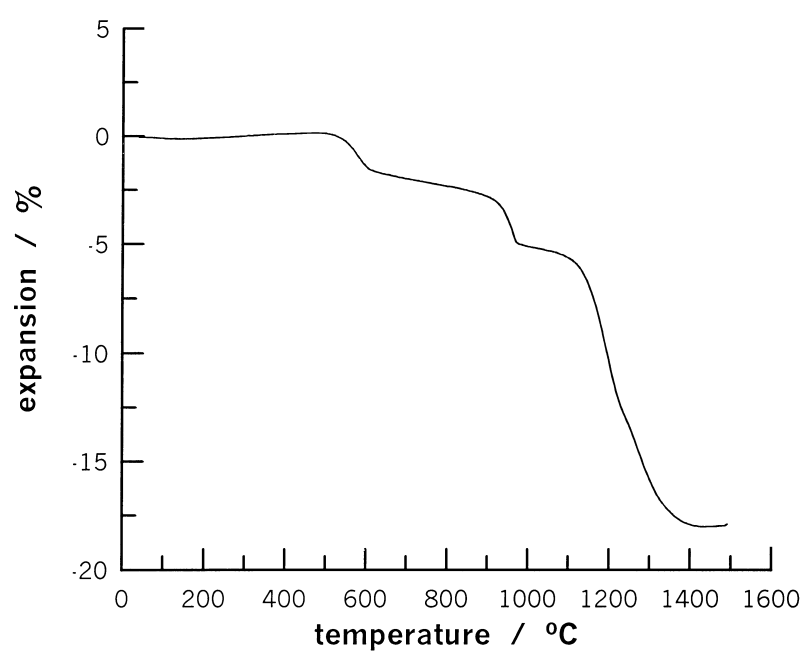

Fig. 5. The sintering kinetics curve of the kaolin powder compact. The heating rate is $5^{\circ} \mathrm{C} / \mathrm{min}$.

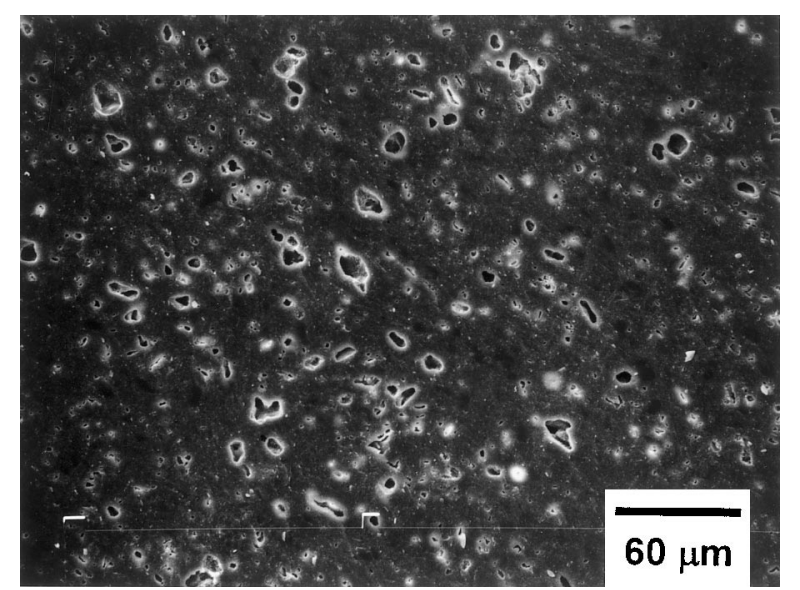

Fig. 6. Fracture surface of the specimen sintered at $1500^{\circ} \mathrm{C}$ for $1 \mathrm{~h}$.

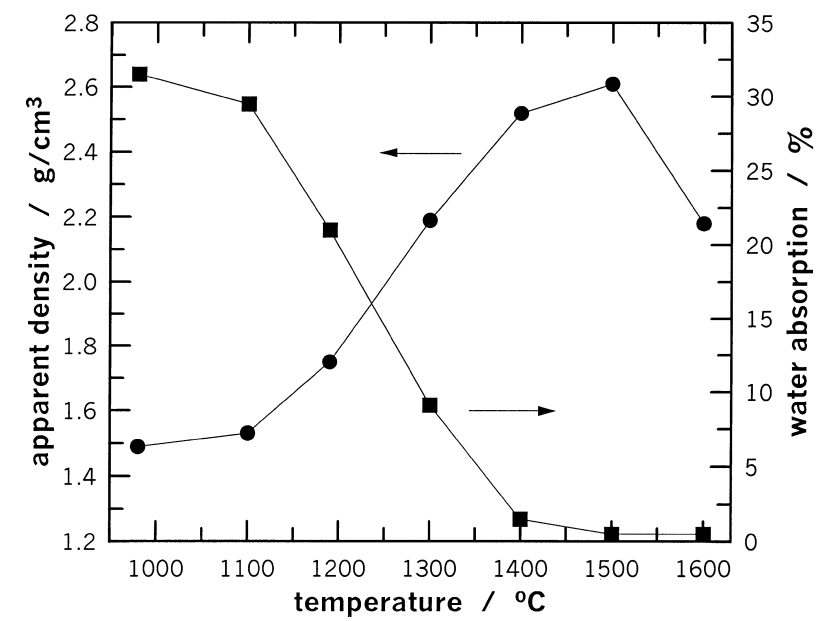

Fig. 7. The fired density and the water absorption of the specimens as a function of sintering temperature.

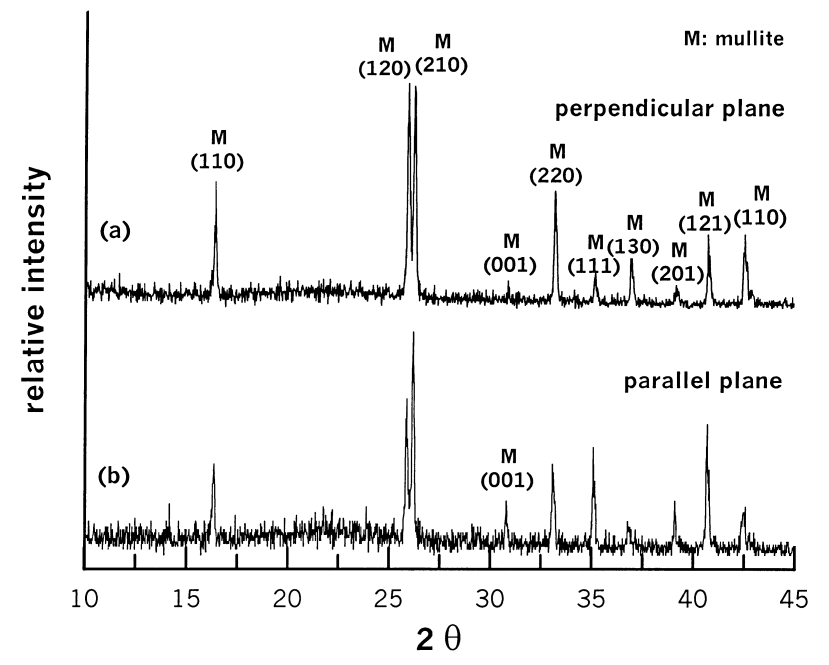

Fig. 8. The XRD patterns of the specimen sintered at $1600^{\circ} \mathrm{C}$ for $1 \mathrm{~h}$. In (a) and (b), the plane taken is perpendicular and parallel to the diepressing direction, respectively.

of the kaolin flakes within the powder compacts. The sintering kinetic curve of kaolin powder compact is shown in Fig. 5. The dimension measured was the thickness of the powder compact. The compact shrinks first at a temperature around $500^{\circ} \mathrm{C}$. At that temperature, the hydroxyl groups are removed from the interlayer between the $\mathrm{Si}-\mathrm{O}$ and $\mathrm{Al}-\mathrm{O}$ layers in the kaolinite crystals. The formation of fine spinel or $\gamma-\mathrm{Al}_{2} \mathrm{O}_{3}$ crystals further shrinks the kaolin compact. The compact then undergoes considerable shrinkage above the temperature of $1100^{\circ} \mathrm{C}$. At that temperature, mullite grains are formed. A liquid phase is likely first formed at a temperature of $985^{\circ} \mathrm{C}$ in the presence of $\mathrm{K}_{2} \mathrm{O}$ [12]. Densification of the compact can, therefore, take place through viscous flow. The presence of nearly spherical pores in the sintered specimens, Fig. 6, shows evidences the existence of the viscous flow mechanism [13]. The fired density and water absorption of the compacts are shown as a function of firing temperature in Fig. 7. The density increases with the increase of firing temperature until $1500^{\circ} \mathrm{C}$. The density drops above $1500^{\circ} \mathrm{C}$, it is due to the presence of $\mathrm{Fe}_{2} \mathrm{O}_{3}$ in the starting powder. The $\mathrm{Fe}_{2} \mathrm{O}_{3}$ changes to $\mathrm{Fe}_{3} \mathrm{O}_{4}$ and generates $\mathrm{O}_{2}$ at elevated temperature [14], large pores are formed within the fired compact, the density is, therefore, decreased.

Fig. 8 shows the XRD patterns of the powder compact sintered at $1600^{\circ} \mathrm{C}$ for $1 \mathrm{~h}$. Only mullite is detected at this temperature. The intensity of the (001) plane on the plane which parallel to the die-pressing direction is higher than that on the plane which is perpendicular to the die-pressing direction. Fig. 9 shows the morphology of mullite grains on the perpendicular planes. The glassy phase was removed by etching the sintered specimens with concentrated HF acid. The size of mullite grains in the specimen sintered at $1400^{\circ} \mathrm{C}$ is very small; nevertheless, 

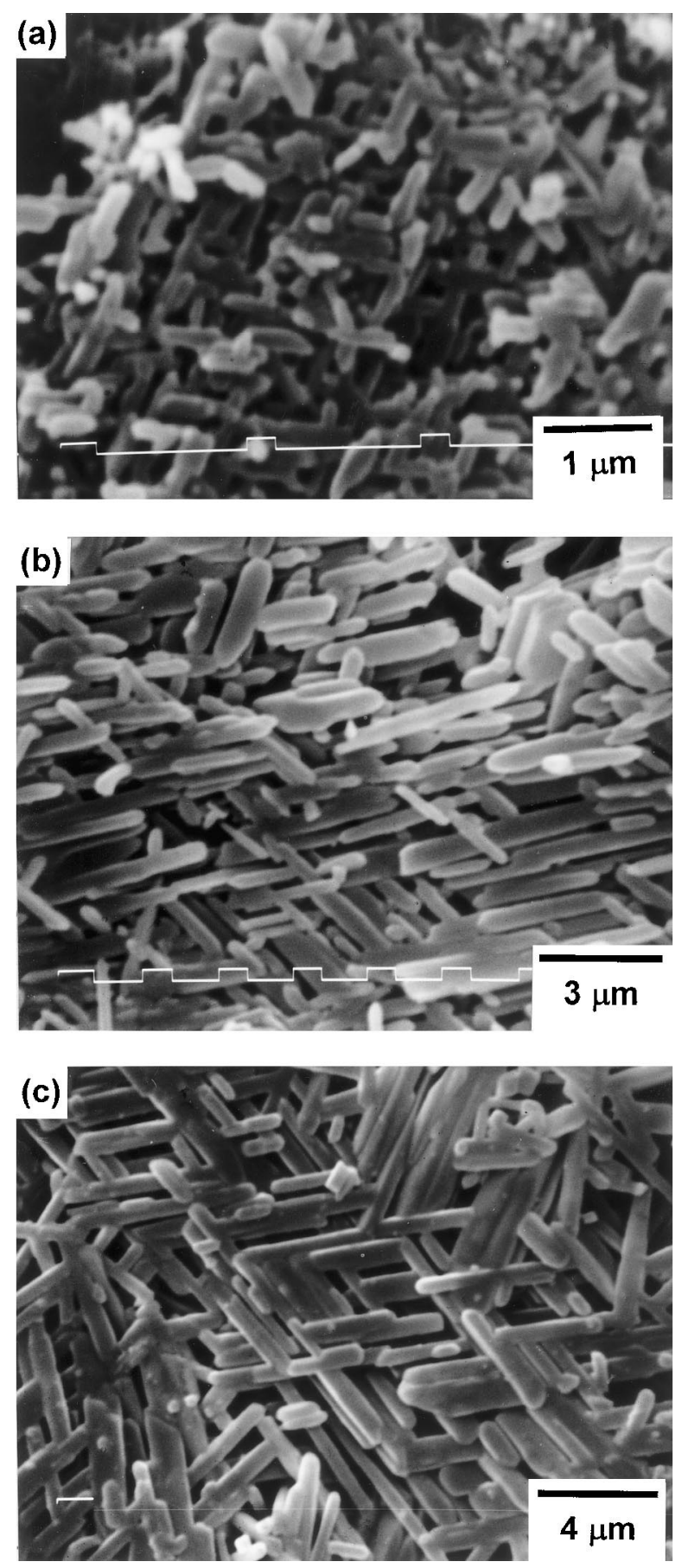

Fig. 9. The morphology of mullite grains on the plane perpendicular to the die-pressing direction in the specimens sintered at (a) $1400^{\circ} \mathrm{C}$, (b) $1500^{\circ} \mathrm{C}$ and (c) $1600^{\circ} \mathrm{C}$ for $1 \mathrm{~h}$. The glassy phase was removed by acid etching.

the mullite grains are needles in shape. The aspect ratio of the mullite needles is 3,5 and 10 in the powder compact sintered at 1400,1500 and $1600^{\circ} \mathrm{C}$, respectively. The aspect ratio increases with the increase of firing temperature. From Fig. 9, most mullite needles tend to lie down on the plane which is perpendicular to the diepressing direction. Previous study suggested that mullite grains tend to form on the surface of kaolinite particles [15]. Comparing the XRD patterns before and after sintering, Figs. 2 and 8, and the microstructure, Fig. 9, the nuclei of mullite grains most likely to have originated from the edge of the kaolinite flakes, then tend to grow along the flat surfaces of the flakes. For the kaolin powder compact which shows preferred orientation, the sintered mullite specimen also shows preferred orientation.

The kaolinite crystal is composed of $\left(\mathrm{Si}_{2} \mathrm{O}_{5}\right)^{-2}$ layer and $\left[\mathrm{Al}_{2}(\mathrm{OH})_{4}\right]^{+2}$ layer. The $\mathrm{Si}$ and $\mathrm{Al}$ ions are stacked sequentially in the direction of c-axis, the $\mathrm{Si}$ and $\mathrm{Al}$ ions are thus "arranged" in atomic order within the kaolinite lattice. The mullitization temperature of the process of using kaolin as starting material is therefore low. The temperature is very close to that of the specimens prepared by a sol-gel technique [5] for which the atomic mixing is achieved. However, mullite needles are formed by using kaolin as the starting material. It may be due to the presence of a large amount of liquid phase. The existence of liquid phase encourages the exposure of low-energy crystallographic faces. Needles which exhibit low-energy faces are, therefore, formed. This unique microstructure is not likely to be found in the specimens prepared by using sol-gel techniques.

The strength of the specimens sintered at 1500 and $1600^{\circ} \mathrm{C}$ are $138 \pm 24$ and $126 \pm 16 \mathrm{MPa}$, respectively. The strength of the specimens sintered at $1600^{\circ} \mathrm{C}$ is lower than that of the specimens sintered at $1500^{\circ} \mathrm{C}$ for their lower density, Fig. 7. The strength of the specimens is lower than that of the pure mullite specimens due to the presence of a large amount of the glassy phase. The toughness of the specimens sintered at 1500 and $1600^{\circ} \mathrm{C}$ is $1.5 \pm 0.1$ and $1.4 \pm 0.1 \mathrm{MPa} \mathrm{m}^{0.5}$, respectively. The toughness of the specimens sintered at 1500 and $1600^{\circ} \mathrm{C}$ shows similar results.

\section{Conclusions}

In the present study, a kaolin powder was used to prepare mullite. The mullite can be formed at a temperature as low as $1100^{\circ} \mathrm{C}$. Furthermore, the mullite grains show a needle shape. The mullite needles are formed in-situ within the powder compacts during sintering. The mullite needles show preferred orientation, being related to the preferred orientation in the kaolin powder compact. Therefore, the advantages of using kaolinite powder as the starting material for mullite preparation are low mullitization temperature and unique microstructure.

\section{References}

[1] F.H. Norton, Fine Ceramics, Technology and Applications, Robert E. Krieger, USA, 1978 (pp. 27). 
[2] W.M. Carty, U. Senapati, Porcelain - raw materials, processing, phase evolution, and mechanical behavior, J. Am. Ceram. Soc. 81 (1998) 3-20.

[3] W.E. Lee, W.M. Rainforth, Ceramic Microstructures - Property Control by Processing, Chapman \& Hall, London, UK, 1994 (pp. 255-312).

[4] M. Bartsch, B. Saruhan, M. Schmucker, H. Schneider, Novel low-temperature processing route of dense mullite ceramics by reaction sintering of amorphous $\mathrm{SiO}_{2}$-coated $\gamma-\mathrm{Al}_{2} \mathrm{O}_{3}$ particle nanocomposites, J. Am. Ceram. Soc. 82 (1999) 1388-1392.

[5] K. Okada, N. Otsuka, Characterization of the spinel phase from $\mathrm{SiO}_{2}-\mathrm{Al}_{2} \mathrm{O}_{3}$ xerogels and the formation process of mullite, J. Am. Ceram. Soc. 69 (1986) 652-656.

[6] G.W. Brindley, M. Nakahira, Kinetics of dehydroxylation of kaolinite and halloysite, J. Am. Ceram. Soc. 40 (1957) 346-350.

[7] G.W. Brindley, M. Nakahira, The kaolinite-mullite reaction series: I, a survey of outstanding problems, J. Am. Ceram. Soc. 42 (1959) 311-314.

[8] G.W. Brindley, M. Nakahira, The kaolinite-mullite reaction series: II, metakalin, J. Am. Ceram. Soc. 42 (1959) 314-318.
[9] G.W. Brindley, M. Nakahira, The kaolinite-mullite reaction series: III, the high-temperature phases, J. Am. Ceram. Soc. 42 (1959) 319-323.

[10] K. Okada, N. Otsuka, J. Osaka, Characterization of spinel phase formed in the kaolin-mullite thermal sequence, J. Am. Ceram. Soc. 69 (1986) c251-c253.

[11] B. Sonuparlak, M. Sarikaya, I. Aksay, Spinel phase formation during $980^{\circ} \mathrm{C}$ exothermic reaction in the kaolinite-to-mullite reaction series, J. Am. Ceram. Soc. 70 (1987) 837-842.

[12] K.-C. Liu, G. Thomas, A. Caballero, J.S. Moya, S. de Aza, Timetemperature-transformation curves for kaolinite- $\alpha$-alumina, J. Am. Ceram. Soc. 77 (1994) 1545-1552.

[13] J.K. Mackenzie, R. Shuttleworth, A phenomenological theory of sintering, Proc. Phys. Soc. London 62 (1949) 633-652.

[14] D. Papargyris, R.D. Cooke, Structure and mechanical properties of kaolin based ceramics, Brit. Ceram. Trans 95 (1996) $107-120$

[15] J. Comer, Electron microscopy studies of mullite development in fired kaolinites, J. Am. Ceram. Soc. 43 (1960) 378-384. 